\title{
Mój pacjent leczony przeciwkrzepliwie - dwa oblicza chorych
}

\author{
My patient treated with oral anticoagulants: two faces of patients
}

\author{
Joanna Wieczorek, Klaudia Gieszczyk-Strózik, Błażej Kusz, Katarzyna Mizia-Stec
}

Katedra i Klinika Kardiologii Wydziału Lekarskiego Śląskiego Uniwersytetu Medycznego w Katowicach

\section{Streszczenie}

W niniejszym opracowaniu przedstawiono 2 chorych z migotaniem przedsionków (AF). Pierwszym pacjentem jest młody mężczyzna, w wieku 46 lat, czynny zawodowo, obciążony jedynie nadciśnieniem tętniczym i dobrze kontrolowaną farmakologicznie nadczynnością tarczycy. Zdiagnozowano u niego przetrwałe od 4 dni AF (EHRA III, 1 pkt w $\mathrm{CHA}_{2} \mathrm{DS}_{2}$-VASc, 0 pkt. w HAS-BLED). Po wykluczeniu w przezprzełykowej echokardiografii (TEE) materiału zatorowego oraz po wdrożeniu leczenia przeciwkrzepliwego lekiem przeciwzakrzepowym niebędącym antagonistą witaminy K (NOAC) wykonano skuteczną kardiowersję elektryczną. Ze względu na nawracające, źle tolerowane epizody AF w obserwacji klinicznej pacjenta zakwalifikowano do ablacji okrążającej żyły płucne (PVI), którą wykonano po rutynowym TEE. U chorego - zarówno około-, jak i pozabiegowo - przez 2 miesiące kontynuowano stosowanie NOAC.

Kolejnym chorym jest 78-letni mężczyzna, leczący się do tej pory przewlekle jedynie z powodu nadciśnienia tętniczego. Został przyjęty na oddział kardiologii z powodu postępującej dekompensacji układu krążenia i nasilonych od 3 tygodni przed przyjęciem objawów niewydolności serca. W trakcie hospitalizacji dodatkowo rozpoznano: przetrwałe AF (EHRA II, $\mathrm{CHA}_{2} \mathrm{DS}_{2}$-VASc 4 pkt, HAS-BLED 3 pkt), umiarkowaną niedomykalność zastawki mitralnej oraz zastawki trójdzielnej, przewlekłą niewydolność nerek w 3. stadium, niedokrwistość mikrocytarną, trombocytopenię, niedobór żelaza, przerost prostaty i chorobę zwyrodnieniową stawów kręgosłupa. Dodatkowym obciążeniem były nieopisywane wcześniej zaburzenia funkcji poznawczych oraz znaczna kruchość pacjenta (4. stopień wg Canadian Study of Health and Aging Clinical Frailty Scale). Po wyrównaniu klinicznym chorego, uwzględnieniu ograniczeń i przeciwwskazań do leczenia przeciwkrzepliwego włączono NOAC i zaplanowano kardiowersję elektryczną w trybie odroczonym.

Multidyscyplinarne podejście do odpowiedniego doboru leczenia przeciwkrzepliwego, zależnie od stanu chorego, planowanych zabiegów przywracających rytm zatokowy (kardiowersji elektrycznej czy PVI) wraz z uwzględnieniem schorzeń współistniejących powinno być priorytetem w codziennej praktyce klinicznej.

Słowa kluczowe: migotanie przedsionków, zaburzenia funkcji poznawczych, zespół kruchości, doustne leki przeciwzakrzepowe

Folia Cardiologica 2016; 11, 6: 542-549

\section{Wstęp}

W artykule przedstawiono opisy 2 chorych z migotaniem przedsionków (AF, atrial fibrillation) różniących się sytuacją kliniczną. Obaj wymagali włączenia adekwatnego leczenia przeciwkrzepliwego i u obu rozważano kardiowersję elektryczną po uwzględnieniu aktualnego stanu klinicznego i przeciwwskazań. 


\section{Opisy przypadków}

\section{Młody pacjent, aktywy zawodowo}

Mężczyzna w wieku 46 lat, czynny zawodowo, został przyjęty w trybie ostrego dyżuru na oddział kardiologii z powodu istotnie gorszego samopoczucia oraz uczucia szybkiego, niemiarowego „bicia serca”. Objawom nie towarzyszyły żadne zamostkowe dolegliwości bólowe ani duszność. Choć dolegliwości pojawiły się 4 dni wcześniej, w przeszłości występowały podobne incydenty, jednak były one znacznie krótsze i z tego powodu lepiej tolerowane. W wywiadzie ponadto chory podawał leczone od około 10 lat nadciśnienie tętnicze oraz rozpoznawaną od niedawna nadczynność tarczycy. Aktualnie sumiennie przyjmował ramipril (dawka $1 \times 10 \mathrm{mg}$ wieczorem) oraz tiamazol (dawka $3 \times 40 \mathrm{mg}$ ). W badaniu przedmiotowym nie ujawniono istotnych nieprawidłowości - był to prawidłowo zbudowany mężczyzna (wskaźnik masy ciała [BMl, body mass index] 21,2 kg mc./ $\mathrm{m}^{2}$ ), osłuchowo stwierdzono nieznacznie zaostrzony szmer pęcherzykowy przypodstawnie nad polami płucnymi, bez szmerów patologicznych nad sercem. Średnie wartości ciśnienia tętniczego w momencie przyjęcia chorego na oddział wynosiły 140-150/90-100 mm Hg, a niemiarowe tętno - do 150/min.

W wykonanych podstawowych badaniach laboratoryjnych nie stwierdzono istotnych odchyleń: wyniki morfologii, elektrolitów, kreatyniny, prób wątrobowych, lipidogramu, wskaźników krzepnięcia krwi. Stężenia hormonu tyreotropowego (TSH, thyrotropin-stimulating hormone) oraz hormonów tarczycy mieściły się w referencyjnych zakresach normy, a parametry zapalne i markery martwicy mięśnia sercowego również pozostawały ujemne (tab. 1).

W wykonanym przy przyjęciu badaniu elektrokardiograficznym zarejestrowano: AF z tachykardią 140-150/ /min, oś pośrednią serca, prawidłową szerokość zespołu QRS (80 ms) oraz odstępu QT (405 ms), bez zmian niedokrwiennych w zakresie odcinka ST-T. W przezklatkowym badaniu echokardiograficznym stwierdzono zachowana globalną frakcję wyrzutową lewej komory (LVEF, left ventricular ejection fraction) wynosząca $52 \%$, bez odcinkowych zaburzeń kurczliwości nieznacznie pogrubiałej lewej komory (grubość przegrody międzykomorowej wyniosła $12 \mathrm{~mm}$, a ściany tylnej $11 \mathrm{~mm}$ ), niewielką dylatację lewego przedsionka z wymiarem przednio-tylnym $43 \mathrm{~mm}$ i powierzchnią $24 \mathrm{~cm}^{2}$ (tab. 1).

Pacjent jest stosunkowo młodą osobą, stroniącą od używek i nadal aktywną zawodowo. W obserwacji klinicznej stosunkowo źle tolerował arytmię (Europejskie Stowarzyszenie Rytmu Serca [EHRA, European Heart Rhythm Association] III) i zdecydowanie preferował w przyszłości utrzymywanie rytmu zatokowego. W skali $\mathrm{CHA}_{2} \mathrm{DS}_{2}$-VASc uzyskał 1 punkt, a w HAS-BLED - 0. W trakcie wstępnie przeprowadzonej rozmowy pacjent wyraził zgodę na kardiowersję elektryczną z okołozabiegową terapią doustnym lekiem przeciwzakrze- powym niebędącym antagonistą witaminy K (NOAC, non-vitamin $\mathrm{K}$ antagonist oral anticoagulant). Uprzedzono go również o możliwości ablacji okrążającej żyły płucne (PVI, pulmonary vein isolation) w celu zapobiegania nawrotom AF w przyszłości.

Rozmowa ta w dużej mierze ukierunkowała dalszą terapię - zdecydowano o wykonaniu kardiowersji elektrycznej. Według zaleceń American College of Cardiology (ACC), American Heart Association (AHA) i Heart Rhythm Society (HRS) z 2014 roku [1] przygotowanie do kardiowersji może przebiegać dwojako: według strategii odroczonej - po zastosowaniu przez 3 poprzedzające tygodnie leczenia przeciwkrzepliwego, należy wykonać kardiowersję w trybie planowym, lub strategii wczesnej - po wykluczeniu skrzepliny w przezprzełykowym badaniu echokardiograficznym (ryc. 1).

Z powodu stwierdzenia złej tolerancji arytmii obrano wczesną strategię przywrócenia rytmu zatokowego. W godzinach rannych wykonano przezprzełykowe badanie echokardiograficzne (TEE, transesophageal echocardiography), które jednoznacznie wykluczyło obecność skrzepliny w uszku lewego przedsionka. Następnie podano choremu 1 dawkę riwaroksabanu (20 mg) i po 4 godzinach wykonano skuteczny zabieg kardiowersji elektrycznej (prądem dwufazowym $150 \mathrm{~J}$ ). Ustalono farmakoterapię, zalecając przy wypisie: riwaroksaban $1 \times 20 \mathrm{mg}$, ramipril $2 \times 10 \mathrm{mg}$, propafenon $3 \times 150 \mathrm{mg}$, leki przeciwtarczycowe według zaleceń endokrynologa oraz regularną kontrolę klirensu kreatyniny ze wskaźnikiem filtracji kłębuszkowej (GFR, glomerular filtration rate) i hemoglobiny przynajmniej jeden raz w roku.

Po kilku miesiącach leczenia chory wrócił do poradni kardiologicznej z powodu częstych, źle tolerowanych (EHRA III) napadów AF trwających 1-2 h, występujących 2-3 razy w tygodniu, a ustępujących po dodatkowej dawce propafenonu. Wobec tego zakwalifikowano go do zabiegu PVI. Nadal stosowano riwaroksaban, przy niezmienionych parametrach nerkowych, a ostatnią dawkę leku podano na 24 godziny przed planowanym zabiegiem ablacji. Rutynowo przed zabiegiem PVI wykonano przezprzełykowe badanie echokardiograficzne, które potwierdziło skuteczność dotychczasowego leczenia. Należy pamiętać, że 1,6-2,1\% chorych, mimo optymalnie prowadzonej antykoagulacji, może mieć skrzeplinę lub sludge w uszku lewego przedsionka, co stanowi istotny problem w trakcie zabiegu PVI (manewrowanie cewnikiem w świetle lewego przedsionka). W kolejnej dobie hospitalizacji wykonano PVI, a po zabiegu kontynuowano dożylny wlew heparyny niefrakcjonowanej pod kontrolą czasu kaolinowo-kefalinowego (APTT, activated partial thromboplastin time). Po 24 godzinach wlew zastąpiono riwaroksabanem w dawce $1 \times 20 \mathrm{mg}$, z zaleceniem kontynuacji przez minimum 2 miesiące. Choremu zalecono stosowanie pozostałych leków, w tym leku antyarytmicznego 
Tabela 1. Wyniki badań laboratoryjnych oraz przezklatkowej echokardiografii 46-letniego chorego

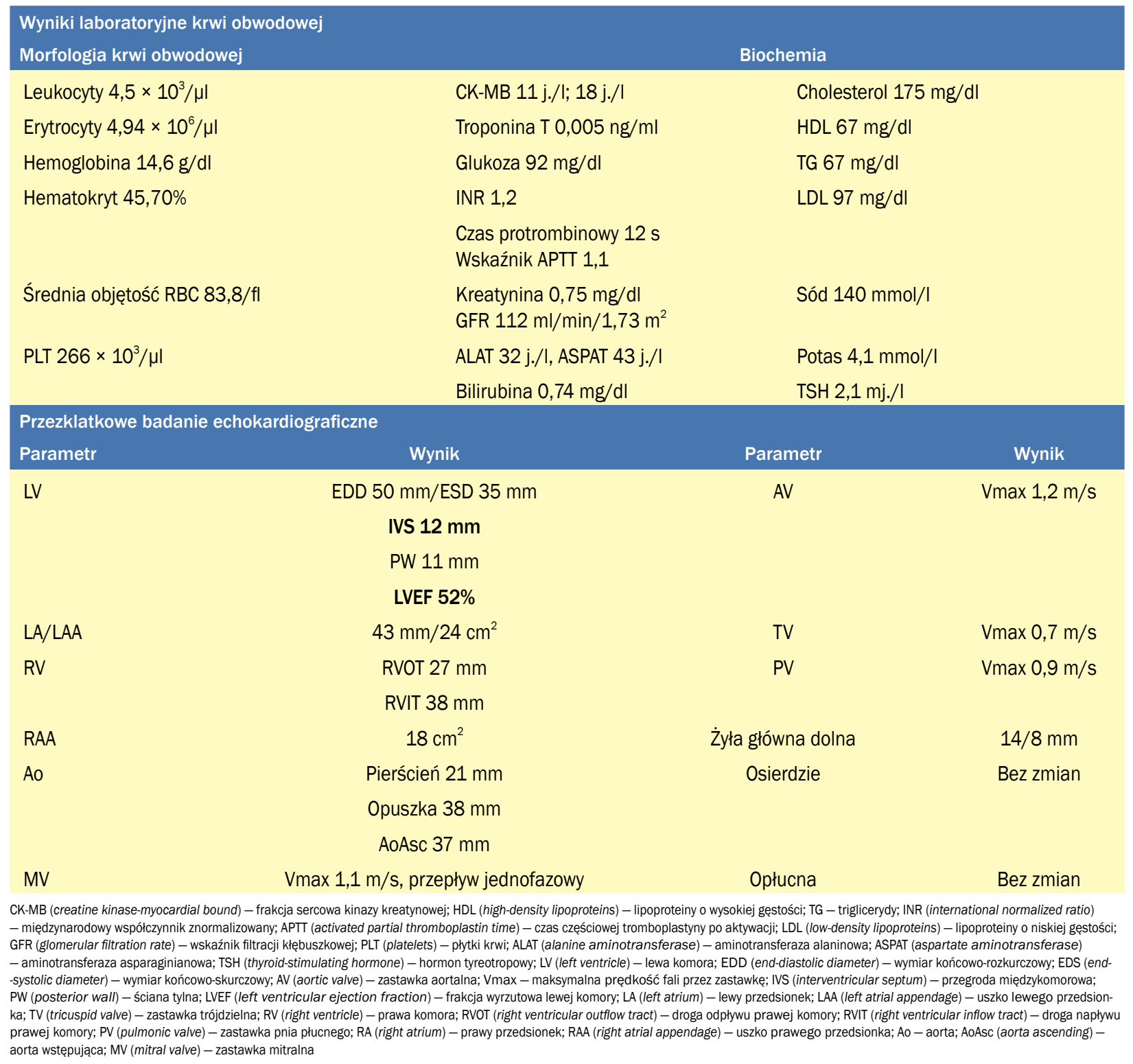

- propafenonu do 3-6 miesięcy od zabiegu, a następnie podjęcie próby odstawienia.

\section{Pacjent w podeszłym wieku z AF i pogarszającą się funkcją poznawczą}

Kolejny chory to mężczyzna w wieku 78 lat, dotychczas niehospitalizowany z przyczyn kardiologicznych. Został przyjęty na oddział kardiologii z powodu postępującej dekompensacji układu krążenia i nasilających się w ciągu poprzedzających 3 tygodni objawów niewydolności serca. Obecna przy przyjęciu rodzina zwracała uwagę na obserwowane w ostatnim czasie pogłębiające się zaburzenia uwagi, apatię, obniżony nastrój oraz zaburzenia pamięci (wcześniej chory funkcjonował prawidłowo). Ponadto w wywiadzie pacjent zgłaszał wieloletnie nadciśnienie tętnicze, leczone farmakologicznie chinaprilem (dawka $2 \times 10 \mathrm{mg}$ ) oraz indapamidem (dawka $1 \times 1,5 \mathrm{mg}$ ), a także przerost prostaty i chorobę zwyrodnieniową kręgosłupa.

W badaniu przedmiotowym spośród nieprawidłowości stwierdzono nieznaczną nadwage (BMI $26 \mathrm{~kg} / \mathrm{m}^{2}$ ), a osłuchowo nad polami płucnymi - obustronne trzeszczenia przypodstawne, ściszony szmer pęcherzykowy u podstawy płuca prawego, a także niemiarową akcję serca 90-100/min z szmerem skurczowym nad sercem. Dodatkowo uwage zwracały znacznego stopnia obrzęki kończyn dolnych oraz podwyższone ciśnienie tętnicze 155/80 mm Hg. W wykonanych przy przyjęciu badaniach laboratoryjnych stwierdzono niskie stężenie hemoglobiny (11 g/dl), płytek krwi (109 tys./ $\mu \mathrm{l}$ ), żelaza $(46 \mu \mathrm{g} / \mathrm{dl})$ oraz nieznacznie podwyższone stęże- 


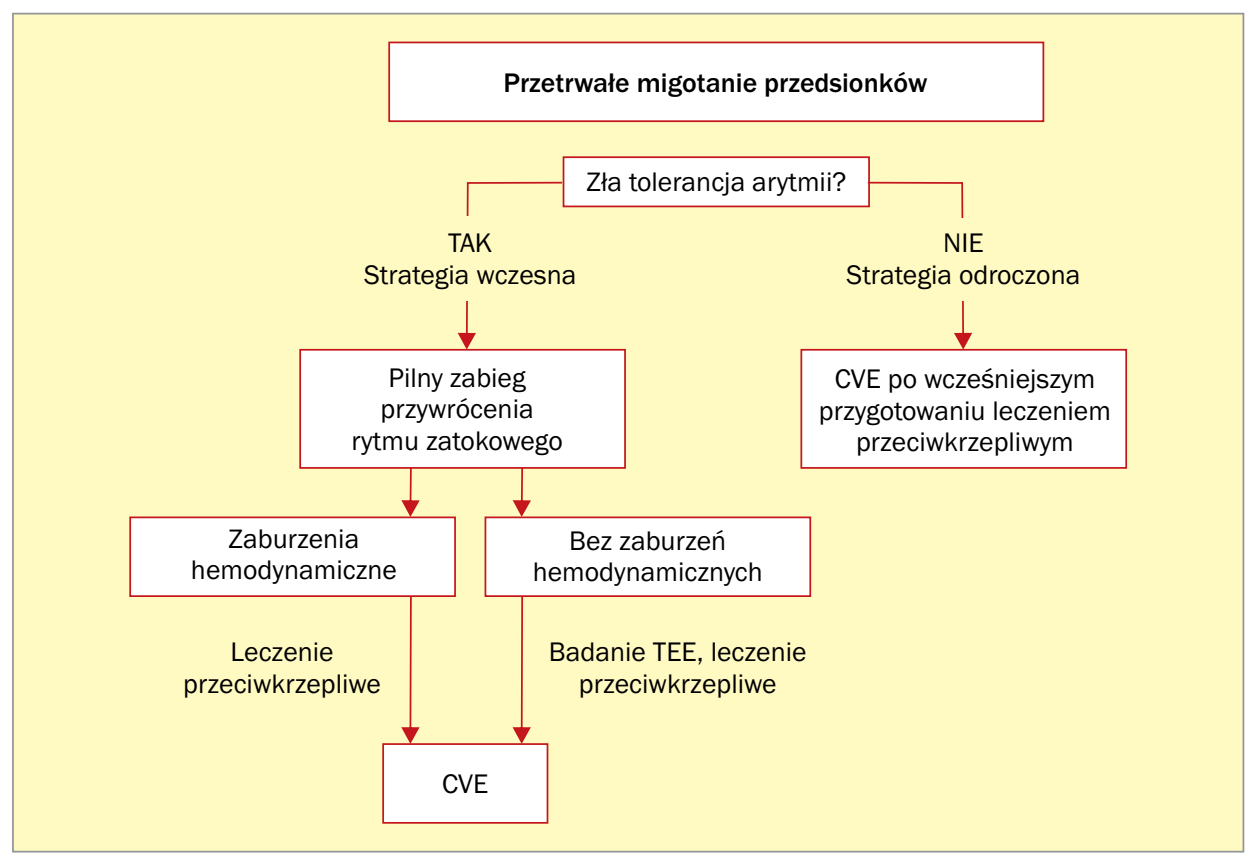

Rycina 1. Schemat przedstawiający wybór strategii wczesnej lub odroczonej leczenia przetrwałego migotania przedsionków w zależności od tolerancji arytmii; CVE (electrical cardioversion) - kardiowersja elektryczna; TEE (transesophageal echocardiography)- echokardiografia przezprzełykowa

nia wysokoczułej troponiny $\mathrm{T}(0,044 \mathrm{ng} / \mathrm{ml}$; w kontroli 0,043 ng/ml), D-dimerów (1986,5 ng/ml) oraz kreatyniny (1,4 mg/dl), GFR (42 ml/min/1,73 m²). Pozostałe parametry krzepnięcia krwi, zapalne, elektrolity, profil lipidowy oraz stężenie enzymów wątrobowych mieściły się w referencyjnych granicach normy (tab. 2).

W spoczynkowym EKG stwierdzono: AF z rytmem komór około 90/min, poszerzony zespół QRS (140 ms), prawidłowy odstęp QT (400 ms) oraz blok lewej odnogi pęczka Hisa. Wywiad zebrany od chorego, ze względu na skąpoobjawowość pacjenta (EHRA II), nie pozwolił jednoznacznie ustalić początku trwania arytmii przedsionkowej, blok lewej odnogi pęczka Hisa także nie był wcześniej opisywany. Wykonane przezklatkowe badanie echokardiograficzne ujawniło nieznacznego stopnia upośledzenie globalnej funkcji skurczowej w niewielkim stopniu pogrubiałej lewej komory (LVEF 45\%, przegroda międzykomorowa $13 \mathrm{~mm}$, ściana tylna lewej komory $11 \mathrm{~mm}$ ), przy prawidłowych wymiarach jam serca (wymiar końcowo-rozkurczowy [EDD, end-diastolic diameter]/wymiar końcowo-skurczowy [EDS, end-systolic diameter] 45/28 mm) oraz nieznacznej dylatacji lewego przedsionka (41 mm/26 cm [2]). Dodatkowo uwage zwracało poszerzenie opuszki $(44 \mathrm{~mm})$ i aorty wstępującej (46 mm), umiarkowane niedomykalności zastawek mitralnej i trójdzielnej oraz płyn w prawej jamie opłucnowej (tab. 2). Diagnostykę obrazową uzupełniono o zdjęcie rentgenowskie klatki piersiowej, w którym potwierdzono niewielką ilość płynu w prawej jamie opłucnowej z niewielkiego stopnia zagęszczeniami miąższu płucnego nad płynem, a w dolnym polu prawego płuca opisano zmiany zapalne niedodmowe (ryc. 2). W wykonanym ponadto dopplerowskim badaniu przepływów przez tętnice szyjne stwierdzono obustronnie przyścienne blaszki miażdżycowe w opuszkach tętnic szyjnych wewnętrznych, bez istotnych zwężeń (wg klasyfikacji NASCET [3]) (ryc. 3), a w koronarografii - obecne niekrytyczne, rozsiane zmiany w tętnicach nasierdziowych.

Co należy brać pod uwagę, dobierając NOAC? Istotne wydaje się uwzględnienie takich czynników jak: wykluczenie jakiegokolwiek krwawienia w ciągu poprzedzających 2 miesięcy, guza wewnątrzczaszkowego lub w innej lokalizacji zagrażającego krwawieniem, małopłytkowości, w tym polekowej (liczba płytek krwi $<50$ tys./ $\mu$ l stanowi przeciwwskazanie do leczenia przeciwkrzepliwego), zaburzeń krzepnięcia, uszkodzenia funkcji wątroby czy nerek (GFR $<30 \mathrm{ml} / \mathrm{min}$ ) oraz stosowanie leków silnie wpływających na cytochrom CYP3A4 i P-glikoproteinę. W przypadku omawianego pacjenta spośród wymienionych czynników występowała u niego przewlekła choroba nerek z GFR $42 \mathrm{ml} / \mathrm{min} / 1,73 \mathrm{~m}^{2}$ (wg Cockcrofta i Gaulta).

Reasumując, u chorego rozpoznano ostatecznie: zastoinową niewydolność krążenia w klasie New York Heart Association (NYHA) III, przetrwałe AF $\left(\mathrm{CHA}_{2} \mathrm{DS}_{2}\right.$-VASC 4 pkt., HAS-BLED 3 pkt.), umiarkowaną niedomykalność zastawki mitralnej oraz zastawki trójdzielnej, nadciśnienie tętnicze, przewlekłą niewydolność nerek w stadium III, niedokrwistość mikrocytarną, trombocytopenię, niedobór żelaza, przerost prostaty i chorobę zwyrodnieniową stawów 
Tabela 2. Wyniki badań laboratoryjnych oraz przezklatkowego badania echokardiograficznego 78-letniego chorego

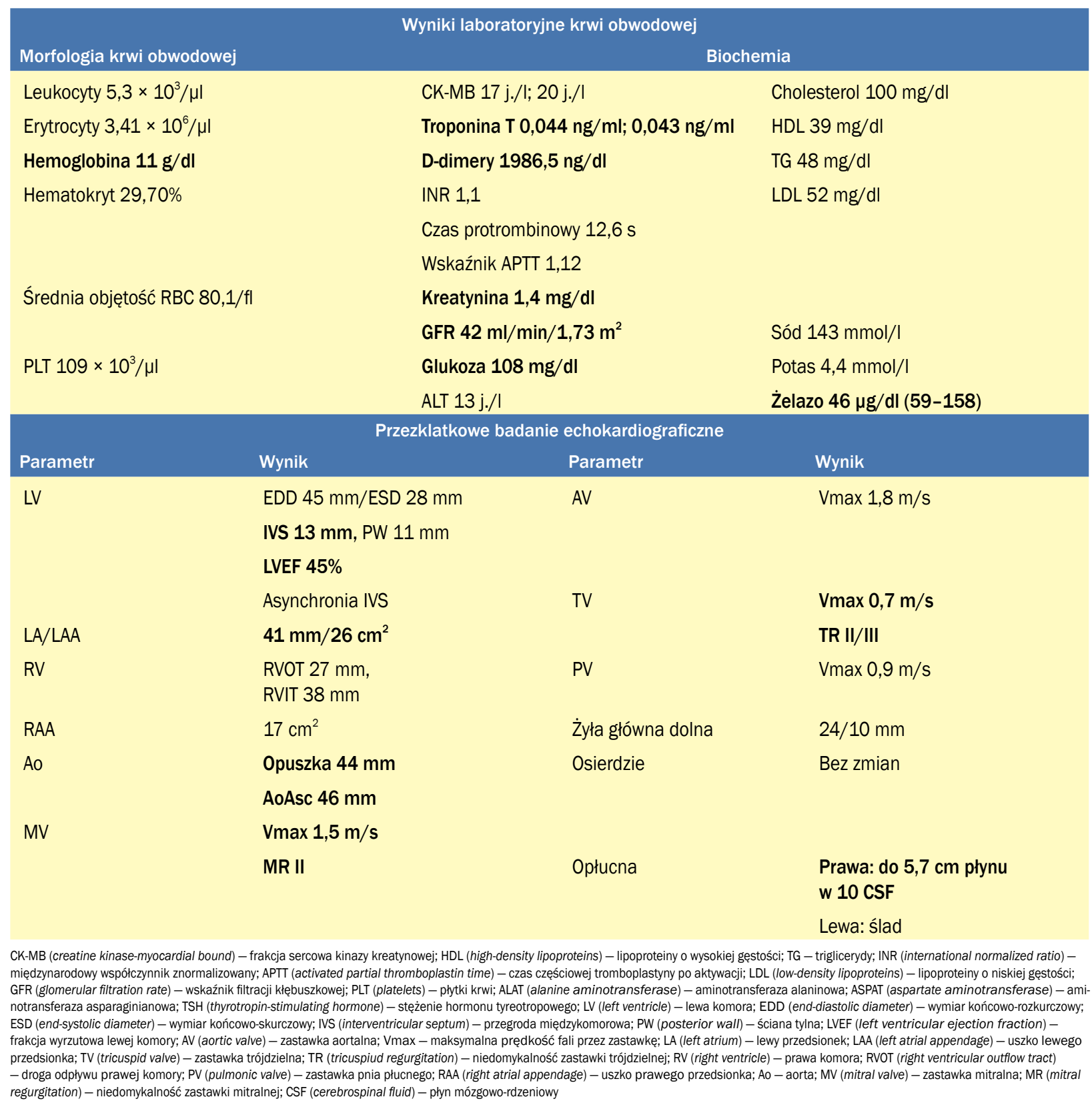

kręgosłupa. Dodatkowo, wykonano rezonans magnetyczny głowy, w którym obrazowano rozsiane hiperintensywne sygnały istoty białej (WMH, white matter hiperintensities) z zanikami korowo-podkorowymi (ryc. 4). Chorego konsultowano neurologiczne. Wobec potwierdzenia zaburzeń uwagi, pamięci, przy prawidłowym badaniu neurologicznym zdiagnozowano u niego zaburzenia poznawcze w przebiegu AF. Warto zaznaczyć, że u pacjenta dodatkowym czynnikiem prowadzącym do nasilenia zaburzeń funkcji poznawczych było najpewniej zaostrzenie choroby podstawowej, czyli nasilenie niewydolności serca skutkujące spadkiem sprawności fizycznej i intelektualnej. Aby dokładniej określić sto- pień samodzielnego funkcjonowania chorego, zastosowano skalę kruchości według Canadian Study of Health and Aging Clinical Frailty Scale (tab. 3). W 7-stopniowej ocenie stan pacjenta określono na 4. stopień.

W trakcie hospitalizacji zastosowano typowe leczenie diuretyczne, wyjściowo dożylne, a następnie doustne diuretykiem pętlowym i eplerenonem. Po włączeniu beta-adrenolityku uzyskano zadowalającą kontrolę częstości rytmu serca, potwierdzoną w 24-godzinnej holterowskiej rejestracji EKG. Kolejnym krokiem było zastąpienie podskórnej heparyny drobnocząsteczkowej adekwatnym do potrzeb pacjenta doustnym antykoagulantem. Biorąc pod 


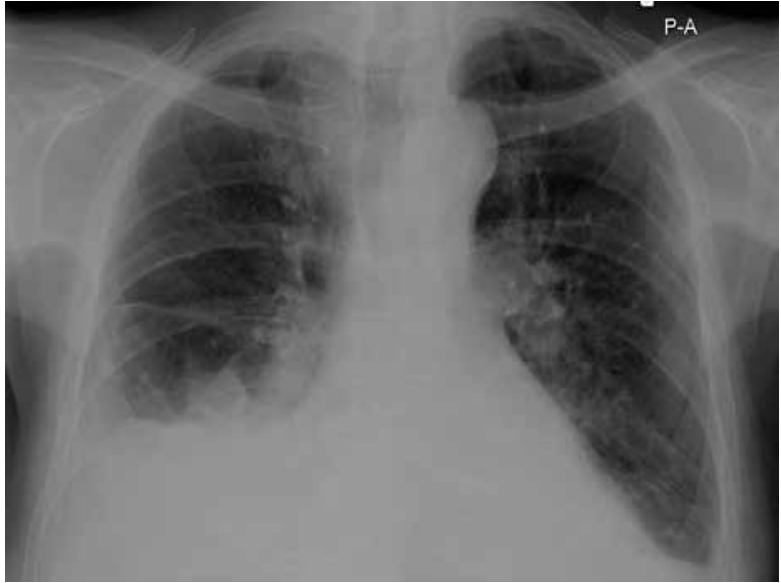

Rycina 2. Badanie radiologiczne klatki piersiowej (wymiar przednio-tylny [P-A, posterior-anterior]) potwierdzające obecność płynu w prawej jamie opłucnowej; dodatkowo opisano niewielkiego stopnia zagęszczenia miąższu płucnego nad płynem, a w dolnym polu prawego płuca zapalne zmiany niedodmowe

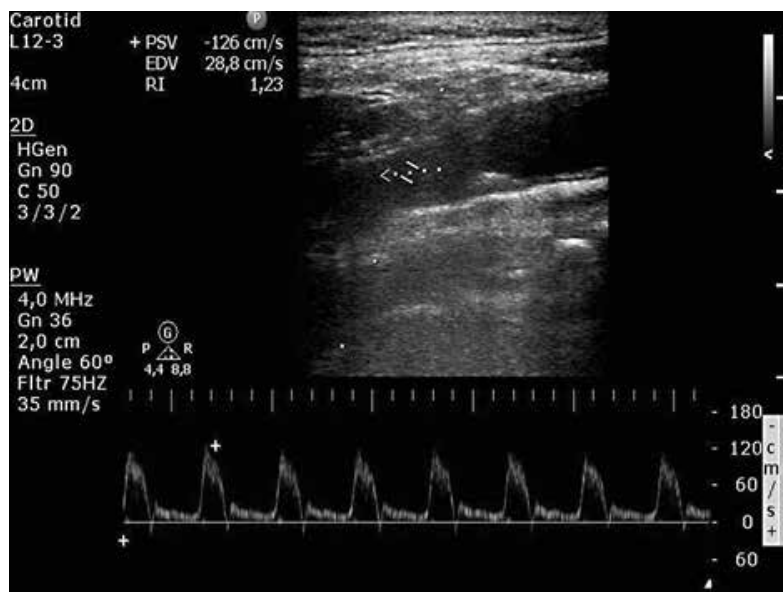

Rycina 3. Doplerowskie badanie ultrasonograficzne tętnic dogłowowych. Widoczna przyścienna blaszka miażdżycowa w tętnicy szyjnej zewnętrznej - nieistotna hemodynamicznie z zachowanym przepływem dogłowowym uwagę bezwzględną zasadność wdrożenia leczenia przeciwkrzepliwego (4 pkt. w $\mathrm{CHA}_{2} \mathrm{DS}_{2}$-VASc) oraz współwystępujące zaburzenia poznawcze, mogące utrudniać prowadzenie skutecznego leczenia antagonistą witaminy $\mathrm{K}$, także uwzględniając preferencje rodziny, zdecydowano o wyborze NOAC - riwaroksabanu lub dabigatranu. Z powodu względnie wysokiego ryzyka potencjalnego krwawienia w skali HAS-BLED (3 pkt.), obniżonego klirensu kreatyniny oraz dodatkowo obserwowanego zespołu kruchości ostatecznie włączono riwaroksaban w dawce 1 raz $15 \mathrm{mg}$. Zaplanowano hospitalizację za miesiąc $w$ celu próby przywrócenia rytmu zatokowego (ryc. 1).

\section{Podsumowanie i wnioski}

W niniejszym opracowaniu przedstawiono opisy przypadków 2 diametralnie różniących się klinicznie chorych obciążonych tą samą arytmią - AF. Obaj wymagali zastosowania skutecznego doustnego antykoagulantu, u obu rozważano wskazania do przywrócenia rytmu zatokowego.

W przypadku pierwszego z nich z powodu złej tolerancji arytmii zdecydowano o wykonaniu kardiowersji elektrycznej z czasowym leczeniem przeciwkrzepliwym okołozabiegowym i po zabiegu. W przypadku drugiego chorego priorytetem było wyrównanie jego stanu z uwzględnieniem ewentualnych pozaarytmicznych przyczyn dekompensacji układu krążenia. Kolejnym krokiem było zarówno włączenie leczenia przeciwkrzepliwego z uwzględnieniem ograniczeń jego stosowania oraz rozważenie wskazań do przywrócenia rytmu zatokowego po wymaganym okresie leczenia doustnym antykoagulantem. Ważnym elementem w doborze leczenia była dokładna ocena schorzeń współistniejących (anemia, funkcja nerek, zaburzenia poznawcze, zespół kruchości) i optymalizacja ich terapii. Za główny długoterminowy cel obrano zapobieganie incydentom zakrzepowo-zatorowym, objawiającym się jako asymptomatyczne incydenty mikrozatorowe mózgu oraz jako najpoważniejsze powikłanie kliniczne - jawny udar
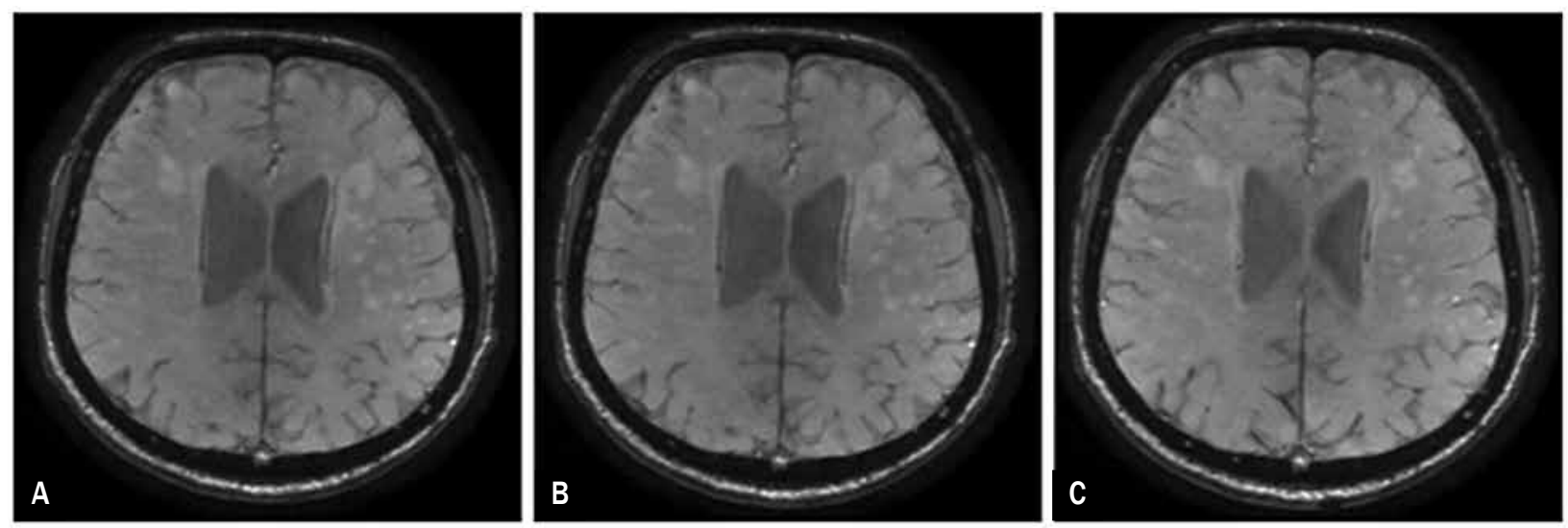

Rycina 4A-C. Badanie rezonansu magnetycznego mózgu. Widoczne ogniska hiperintensywnych sygnałów istoty szarej (pojedyncze oraz zlewające się) oraz rozsiana atrofia korowo-podkorowa 
Tabela 3. Skala kruchości według Canadian Study of Health and Aging Clinical Frailty Scale

$\begin{array}{ll}\text { Kategoria } & \text { Charakterystyka osób } \\ \begin{array}{ll}\text { 1. Bardzo dobra kondycja } & \begin{array}{l}\text { Aktywne, energiczne, dobrze zmotywowane i zdrowe; uprawiają regularnie ćwiczenia } \\ \text { i należą do najzdrowszych w swoim przedziale wiekowym }\end{array} \\ \begin{array}{l}\text { 2. Dobra kondycja } \\ \begin{array}{l}\text { 3. Dobra kondycja, leczone choroby } \\ \text { współistniejące }\end{array}\end{array} & \begin{array}{l}\text { Objawy chorób są dobrze kontrolowane w porównaniu z osobami z kategorią } 4 . \\ \text { 4. Częściowa podatność }\end{array} \\ \begin{array}{l}\text { 5. Łagodna kruchość } \\ \text { 6. Umiarkowana kruchość }\end{array} & \text { Ciezależnie od pomocy innych często zgłaszają „spowolnienie” lub objawy istniejących chorób od pomocy innych w codziennym życiu } \\ \text { 7. Poważna kruchość } & \text { Wymagają częstej pomocy w codziennym życiu }\end{array} \\ \end{array}$

mózgu. W tym przypadku strategia przywrócenia rytmu zatokowego została odroczona.

Warto podkreślić, że AF istotnie zwiększa ryzyko dysfunkcji pamięci w postaci łagodnych zaburzeń poznawczych oraz pełnoobjawowego otępienia, zarówno na podłożu choroby Alzheimera, jak i o charakterze naczyniopochodnym. Pacjenci z AF oraz współwystępującymi zaburzeniami poznawczymi obciążeni są istotnie gorszym rokowaniem. Jednocześnie samo wystąpienie zaburzeń poznawczych wywiera istotny wpływ zwrotny na prawidłowe leczenie przeciwkrzepliwe (nieterapeutyczny międzynarodowy współczynnik znormalizowany [INR, international normalized ratio] w przypadku antagonistów witaminy $\mathrm{K}$, nieregularne przyjmowanie zaleconych dawek leków). Z kolei compliance chorego jest kluczowy w skutecznej prewencji powikłań zakrzepowo-za- torowych i zahamowaniu progresji zaburzeń pamięci. Dowiedziono, że prowadzenie skutecznego leczenia przeciwkrzepliwego znosi niekorzystne efekty zaburzeń poznawczych na rokowanie u chorych z AF [4]. Ponadto sama kontrola rytmu i częstości rytmu jest kluczowa w prewencji pogłębiania się zaburzeń poznawczych i rozwoju otępienia [5].

Multidyscyplinarne podejście w dobieraniu i optymalizacji leczenia przeciwkrzepliwego powinno być dostosowane do potrzeb chorego z uwzględnieniem chorób towarzyszących, ryzyka zakrzepowo-zatorowego oraz planowanych procedur leczniczych.

\section{Konflikt interesów}

Autorzy nie zgłaszają konfliktu interesów.

\section{Abstract}

This paper presents two patients with atrial fibrillation. The first patient is a young 46-year-old, working, active male, who has only hypertension and pharmacologically well-controlled hyperthyroidism. He was diagnosed with persistent atrial fibrillation lasting four days (EHRA III, $\mathrm{CHA}_{2} \mathrm{DS}_{2}$-VASc 1 point, HAS-BLED 0 point). After excluding embolic material based on the transesophageal echocardiography and implementation of non-vitamin $\mathrm{K}$ antagonist oral anticoagulant (NOAC), effective electrical cardioversion was performed. Due to poorly tolerated recurrences of atrial fibrillation (EHRA III) in the clinical observation, the patient has been classified for circumferential pulmonary vein isolation (PVI), which was performed after a routine transesophageal echocardiography. The patient continued anticoagulation with NOAC before and post procedure for 2 months.

Another patient is a 78-year-old man, treated chronically, so far only because of hypertension. He was admitted to the cardiology department due to the cardiovascular decompensation and increased symptoms of heart failure for 3 weeks prior to hospitalization. During the hospitalization, the patient was diagnosed with persistent atrial fibrillation (EHRA II, $\mathrm{CHA}_{2} \mathrm{DS}_{2}$-VASc 4 points, HAS-BLED 3 points), moderate mitral and tricuspid valve regurgitation, chronic renal failure stage III, microcytic anemia, thrombocytopenia, iron deficiency, benign prostatic hypertrophy and osteoarthritis of the spine. Additional aggravating factors were newly diagnosed cognitive function decline and considerable fragility of the patient (4th degree according to the Canadian Study of Health and Aging Clinical Frailty Scale). After the improvement of the patient status, taking into account the limitations and contraindications to anticoagulation, NOAC was administered. Electrical cardioversion was planned during next hospitalization. 
Multidisciplinary approach to the choice of appropriate anticoagulant therapy, depending on the patient's condition, the planned treatment for restoring sinus rhythm (cardioversion or PVI) with regard to comorbidities, should be a priority in everyday clinical practice.

Key words: atrial fibrillation, cognitive function decline, fragility syndrome, oral anticoagulants

Folia Cardiologica 2016; 11, 6: 542-549

\section{Piśmiennictwo}

1. January C.T., Wann L.S., Alpert J.S. i wsp. 2014 AHA/ACC/HRS guideline for the management of patients with atrial fibrillation: a report of the American College of Cardiology/American Heart Association Task Force on Practice Guidelines and the Heart Rhythm Society. J. Am. Coll. Cardiol. 2014; 64: e1-e76.

2. Ezekowitz M.D., Cappato R., Klein A.L. i wsp. Rationale and design of the eXplore the efficacy and safety of once-daily oral riVaroxaban for the prEvention of caRdiovascular events in patients with nonvalvular aTrial fibrillation scheduled for cardioversion trial: a comparison of oral rivaroxaban once daily with dose-adjusted vitamin $\mathrm{K}$ antagonists in patients with nonvalvular atrial fibrillation undergoing elective cardioversion. Am. Heart J. 2014; 167: 646-652.
3. Moneta G.L., Edwards J.M., Chitwood R.W. i wsp. Correlation of North American Symptomatic Carotid Endarterectomy Trial (NASCET) angiographic definition of $70 \%$ to $99 \%$ internal carotid artery stenosis with duplex scanning. J. Vasc. Surg. 1993; 17: 152-157; dyskusja 7-9.

4. Flaker G.C., Pogue J., Yusuf S. i wsp. Cognitive function and anticoagulation control in patients with atrial fibrillation. Circ. Cardiovasc. Qual. Outcomes 2010; 3: 277-283.

5. Cacciatore F., Testa G., Langellotto A. i wsp. Role of ventricular rate response on dementia in cognitively impaired elderly subjects with atrial fibrillation: a 10-year study. Dement Geriatr. Cogn. Dis. 2012; 34: $143-148$ 